\title{
Demographics, Interests, and Quality of Life of Canadian Neurosurgery Residents
}

\author{
Christian Iorio-Morin, Syed Uzair Ahmed, Mark Bigder, Ayoub Dakson, \\ Cameron Elliott, Daipayan Guha, Michelle Kameda-Smith, Pascal Lavergne, \\ Serge Makarenko, Michael S. Taccone, Michael K. Tso, Bill Wang, Alexander \\ Winkler-Schwartz, David Fortin on behalf of the Canadian Neurosurgery \\ Research Collaborative
}

\begin{abstract}
Background: Neurosurgical residents face a unique combination of challenges, including long duty hours, technically challenging cases, and uncertain employment prospects. We sought to assess the demographics, interests, career goals, self-rated happiness, and overall well-being of Canadian neurosurgery residents. Methods: A cross-sectional survey was developed and sent through the Canadian Neurosurgery Research Collaborative to every resident enrolled in a Canadian neurosurgery program as of April 1, 2016. Results: We analyzed 76 completed surveys of 146 eligible residents (52\% response rate). The median age was 29 years, with $76 \%$ of respondents being males. The most popular subspecialties of interest for fellowship were spine, oncology, and open vascular neurosurgery. The most frequent self-reported number of worked hours per week was the 80- to 89-hour range. The majority of respondents reported a high level of happiness as well as stress. Sense of accomplishment and fatigue were reported as average to high and overall quality of life was low for $19 \%$, average for $49 \%$, and high for $32 \%$. Satisfaction with work-life balance was average for $44 \%$ of respondents and was the only tested domain in which significant dissatisfaction was identified (18\%). Overall, respondents were highly satisfied with their choice of specialty, choice of program, surgical exposure, and work environment; however, intimidation was reported in $36 \%$ of respondents and depression by $17 \%$. Conclusions: Despite a challenging residency and high workload, the majority of Canadian neurosurgery residents are happy and satisfied with their choice of specialty and program. However, work-life balance, employability, resident intimidation, and depression were identified as areas of active concern.
\end{abstract}

RÉSUMÉ: Caractéristiques sociodémographiques, intérêts et qualité de vie des médecins résidents en neurochirurgie au Canada. Contexte: Les médecins résidents en neurochirurgie font face à une combinaison unique de défis, notamment de longues heures de travail, des cas complexes sur le plan technique et des perspectives d'emploi incertaines. Nous avons ainsi cherché à évaluer leurs caractéristiques sociodémographiques, leurs intérêts, leurs objectifs de carrière, leur degré de satisfaction personnelle ainsi que leur bien-être général. Méthodes: Nous avons élaboré une enquête transversale qui, par l'entremise du Canadian Neurosurgery Research Collaborative, a été par la suite envoyée à chaque médecin résident inscrit, en date du $1^{\text {er }}$ avril 2016, à un programme canadien de neurochirurgie. Résultats: Sur un total de 146 médecins résidents admissibles, nous avons reçu et analysé 76 formulaires d'enquête remplis, ce qui représente un taux de réponse de $52 \%$. L'âge médian des répondants était de 29 ans ; $76 \%$ d'entre eux étaient de sexe masculin. Parmi les sous-spécialités les plus populaires dans le cadre d'une activité de recherche ultérieure, mentionnons celles portant sur la colonne vertébrale, l'oncologie et la neurochirurgie vasculaire ouverte. La plupart des répondants ont par ailleurs indiqué avoir travaillé entre 80 et 89 heures par semaine. La majorité d'entre eux ont aussi fait état d'un degré élevé de satisfaction personnelle et de stress ; de plus, tant leur sentiment de réussite que leur fatigue ont été évalués comme moyens à élevés. Quant à leur qualité de vie en général, $19 \%$ des médecins résidents ont affirmé qu'elle était faible ; $49 \%$, qu'elle était moyenne ; et $32 \%$, qu'elle était élevée. En outre, $44 \%$ ont considéré que leur niveau de satisfaction en matière de conciliation travail-vie personnelle était moyen. Ce dernier aspect est d'ailleurs le seul dont l'évaluation nous a permis d'identifier une insatisfaction notable, soit $18 \%$. De façon générale, on peut dire que les répondants se sont dits très satisfaits de leur choix de spécialité et de programme, de leur fréquence passée à observer des interventions chirurgicales et de leur environnement de travail. Toutefois, $36 \%$ d'entre eux ont rapporté avoir été victimes d'intimidation tandis que $17 \%$ ont affirmé avoir éprouvé des symptômes de dépression. Conclusions: Bien que les programmes de résidence en

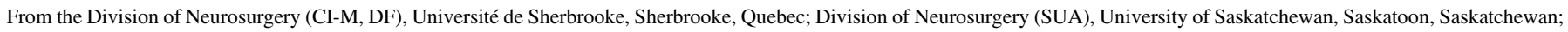

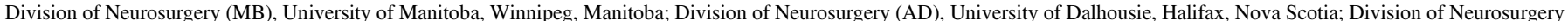
(CE), University of Alberta, Edmonton, Alberta; Division of Neurosurgery (DG), University of Toronto, Toronto, Ontario; Division of Neurosurgery (MK-S), McMaster University,

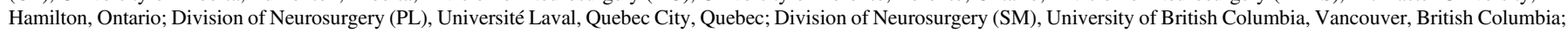
Division of Neurosurgery (MST), University of Ottawa, Ottawa, Ontario; Division of Neurosurgery (MKT), Calgary University, Calgary, Alberta; Division of Neurosurgery (BW),

University of Western Ontario, London, Ontario; Division of Neurosurgery (AW-S), McGill University, Montreal, Quebec.

Received April 25, 2017. Final Revisions Submitted August 20, 2017. Date of Acceptance August 25, 2017.

Correspondience to: Christian Iorio-Morin, Division of Neurosurgery, Centre Hospitalier Universitaire de Sherbrooke, 3001, 12e Avenue Nord, Sherbrooke, QC, Canada, J1H 5N4.

Email: christian.iorio-morin@usherbrooke.ca. 
neurochirurgie soient exigeants et comportent un volume de travail important, la majorité des médecins résidents du Canada se disent heureux et satisfaits de leur choix de spécialité et de programme. Cela dit, la conciliation travail-vie personnelle, l'employabilité, l'intimidation et la dépression ont été identifiées comme des sujets de grande préoccupation.

Keywords: fellowship, happiness, quality of life, satisfaction, Workload

doi:10.1017/cjn.2017.263

Can J Neurol Sci. 2018; 45: 214-220

Neurosurgery is a highly competitive residency, with few positions available to many applicants. ${ }^{1}$ Despite the nearly universal high motivation, impressive academic record, and good medical school ranking of accepted trainees, programs have historically been plagued with a $43 \%$ attrition rate. ${ }^{2,3}$ Among the potential risk factors identified were dissatisfaction with lifestyle, ${ }^{2}$ female gender, ${ }^{4}$ and attitude of senior residents and staff. ${ }^{3}$ As admissions in Canadian programs were increased to compensate an anticipated shortage in the workforce, ${ }^{5}$ neurosurgery itself became much more subspecialized, ${ }^{6}$ challenging the adequacy of surgical exposure for each trainee. ${ }^{7}$ In the end, workforce shortage never materialized and, combined with the decision of the American Board of Neurological Surgeons to stop recognizing Canadian residency training, graduates recently found themselves worrying about unemployment. ${ }^{8,9}$

Neurosurgery residents therefore face a unique combination of challenges including a high-workload, high-stakes specialty following a 6-year long residency with uncertain employment prospects. To identify characteristics of such individuals, we performed a cross-sectional survey of Canadian neurosurgery residents and fellows assessing three domains: demographics, interests and career goals, as well as happiness and well-being.

\section{Methods}

\section{Study Population}

All neurosurgery residents or fellows enrolled in a Canadian postgraduate program as of April 1, 2016, were eligible for participation. Residents who had been accepted at but had not yet started their neurosurgical residency program were excluded from the study. Potential respondents were identified through the Canadian Neurosurgery Research Collaborative (CNRC), which includes a local resident representative at 12 of the 14 neurosurgery programs in Canada. ${ }^{10}$ Potential respondents from the remaining institutions were reached through a contact with one of the institution's residents. The study took the form of an online survey to be completed at the participant's convenience within 8 weeks of study start.

\section{Survey Development}

A 40-question online survey was developed by the first author. The survey specifically explored three domains: (1) demographics, (2) interests and career goals, and (3) happiness and well-being. A meeting of the CNRC members was held to assess face and content validity. The survey was improved and the final version approved by all authors. The distributed survey is available as Supplementary Material 1.

Most questions consisted of either multiple choice questions or five-level Likert scales. Overall quality of life and satisfaction with choice of specialty and work-life balanced were specifically assessed in this way to match reports from other specialties. ${ }^{11-15}$ Responses to Likert questions were condensed to three levels for the analysis (i.e. "strongly agree" and "agree" grouped together and "strongly disagree" and "disagree" grouped together).

\section{Survey Administration}

All Canadian residents and fellows received an invitation to participate in the study and a link to the survey website. A general e-mail reminder was sent after 2 and 4 weeks. After 6 weeks, nonrespondents were contacted directly by their local CNRC representative to encourage participation. Response collection was stopped after 8 weeks.

\section{Statistical Analysis}

As per the guidelines of the American Association for Public Opinion Research, surveys were considered completed if more than $80 \%$ of the questions were answered. ${ }^{16}$ Only completed surveys were included in the analysis.

Survey answers are presented using frequency tables with the number of respondents to each answer and valid percentages. Continuous variables are reported using the median and range. The independence of categorical variables was assessed using the chi-square test. All statistical analyses were performed in IBM SPSS Statistics, version 24.0.0.0 (IBM, Armonk, NY). Figures were produced using Prism 6.0 (GraphPad Software Inc., La Jolla, CA) and Adobe Illustrator CS6, version 16.0.4 (Adobe Systems, San Jose, CA).

\section{Ethics, Consent, and Permissions}

This study was approved by the Research Ethics Board of the Centre Hospitalier Universitaire de Sherbrooke and by the CNRC steering committee. Consent to publish anonymized, aggregated data was obtained as part of the general consent for study participation.

\section{Results \\ Survey Response Rate}

A total of 146 residents and 25 fellows were identified as potentially eligible for study participation by CNRC representatives. We received surveys from 77 (53\%) residents and four (16\%) fellows. Given the poor response rate among fellows, we decided to exclude them from the analysis and focus exclusively on residents. One resident survey was incomplete and was excluded (Figure 1), leading to a final analysis of 76 completed resident surveys (52\% response rate). Response rate varied between programs, ranging from $0 \%$ to $83 \%$. All provinces and residency training levels were proportionally represented. 
Table 1: Demographics of survey respondents (Canadian neurosurgery residents and fellows)

\begin{tabular}{l|c}
\hline & $\mathbf{n}$ \\
\hline Sex & \\
\hline Female & $19(25 \%)$ \\
\hline Male & $57(75 \%)$ \\
\hline Median age (range) & $29(24-37)$ \\
\hline Level & \\
\hline PGY-1 & $12(16 \%)$ \\
\hline PGY-2 & $11(14 \%)$ \\
\hline PGY-3 & $16(21 \%)$ \\
\hline PGY-4 & $16(21 \%)$ \\
\hline PGY-5 & $12(16 \%)$ \\
\hline PGY-6 & $9(12 \%)$ \\
\hline Marital status & \\
\hline Married & $29(38 \%)$ \\
\hline Common law & $18(24 \%)$ \\
\hline Single & $29(38 \%)$ \\
\hline Children & \\
\hline No children & $15(1 \%)$ \\
\hline 1 & $54(71 \%)$ \\
\hline 2 & $15(20 \%)$ \\
\hline 3 & $6(8 \%)$ \\
\hline PGY & $1(1 \%$ \\
\hline
\end{tabular}

$\mathrm{PGY}=$ postgraduate year.

\section{Demographics}

The demographics of respondents are presented in Table 1. Briefly, $75 \%$ were male, $38 \%$ were married, and $71 \%$ had no children. The median age was 29 years. During their respective

\section{Table 2: Residency matching statistics}

\begin{tabular}{l|r}
\hline & n (\%) \\
\hline $\begin{array}{l}\text { Was neurosurgery your first choice of specialty when you } \\
\text { applied in CaRMS? }\end{array}$ & $69(96)$ \\
\hline Yes & $3(4)$ \\
\hline No & \\
\hline $\begin{array}{l}\text { How did you rank your residency program among the other } \\
\text { neurosurgery programs when you applied in CaRMS? }\end{array}$ & $54(75)$ \\
\hline First choice & $14(20)$ \\
\hline Second choice & $3(4)$ \\
\hline Third choice & $1(1)$ \\
\hline Fourth +choice & $8(11)$ \\
\hline Prior research experience & $51(67)$ \\
\hline No research experience & $28(37)$ \\
\hline Summer research project & $11(15)$ \\
\hline BSc & $3(4)$ \\
\hline MSc & \\
\hline PhD & \\
\hline
\end{tabular}

$\mathrm{CaRMS}=$ Canadian Resident Matching Service.
Canadian Resident Matching Service application, neurosurgery was the first choice of specialty for $96 \%$ of respondents, and $75 \%$ were matched to their first-ranked neurosurgical program (Table 2). Most respondents had some research experience before beginning residency, but their prior research exposure was not associated with a higher chance of matching in their first choice of program $(73.4 \% \mathrm{vs}$ $87.5 \%$ for residents with or without prior research experience, respectively; Pearson chi-square $(3)=.911, p=0.823$ ).

\section{Interests and Career Planning}

Following residency training, $86 \%$ indicated that they plan to complete a fellowship (Table 3), with the most popular subspecialties being spine, oncology, and open vascular neurosurgery (Figure 2). The United States was the most popular anticipated site for fellowship training. Seventy-five percent of respondents stated they plan to incorporate research as part of their practice, with $57 \%$ planning to pursue advanced research training (masters of science or doctorate) during residency. The majority of respondents $(80 \%)$ would endeavor to practice in an academic institution, with $59 \%$ ideally practicing in Canada. Twenty-five percent were unsure in which country they would like to practice and only $37 \%$ felt confident in finding a job. Interestingly, a nonstatistically significant trend was observed in which pursing an additional research degree was associated with a lack of confidence in finding a job (28\% vs 52\% feeling confident among the respondents planning vs not planning an additional degree, Pearson chi-square $(2)=5.843, p=0.054)$.

\section{Workload}

The most frequent self-reported number of worked hours per week (including calls) was the 80 - to 89 -hour range, with $21 \%$ stating they typically worked more than 100 hours per week (Figure 3). This workload was deemed reasonable by $58 \%$ and too much by $41 \%$ of respondents. The median number of days on call per month was 7 (range, 0-12), with most feeling this number was reasonable $(66 \%)$ or too high $(34 \%)$.

\section{Happiness and Well-Being}

Happiness and well-being measures are presented in Table 4. Overall, the majority of respondents reported both a high level of happiness as well as stress. Sense of accomplishment and fatigue were reported as average to high. Overall quality of life was low for $18 \%$, average for $49 \%$, and high for $33 \%$. Satisfaction with work-life balance was average for $46 \%$ of respondents and was the only tested domain in which significant dissatisfaction was identified (17\%). Overall, respondents were highly satisfied with their choice of specialty, choice of program, surgical exposure, and work ambiance.

Of note, $35 \%$ of respondents reported having been victim of intimidation during residency. Depression was experienced by $17 \%$, and $4 \%$ considered suicide. Intimidation was statistically significantly associated with depression (Pearson chi-square (4) $=19.107, p=0.001)$.

\section{DISCUSSION}

\section{Demographics and Career Planning}

The demographics of Canadian neurosurgery residents was remarkably similar to that of their American ${ }^{17}$ and European ${ }^{18}$ colleagues, with an average age of 30 years, the majority being 
Table 3: Career planning

\begin{tabular}{|c|c|c|c|c|}
\hline & n & Yes & Neutral/unsure & No \\
\hline Median expected length of residency (excluding fellowship) in years (range) & $6.5(6-10)$ & & & \\
\hline \multicolumn{5}{|l|}{ Reason for extension of residency $(\%)$} \\
\hline No planned extension & $31(41)$ & & & \\
\hline Additional degree/research & $43(57)$ & & & \\
\hline Repeat rotations & $2(3)$ & & & \\
\hline Personal reasons & $3(4)$ & & & \\
\hline Health reasons & $0(0)$ & & & \\
\hline \multicolumn{5}{|l|}{$\begin{array}{l}\text { Have you completed or are you pursuing an additional degree } \\
\text { (excluding fellowship) during your residency? }(\%)\end{array}$} \\
\hline No & $30(39)$ & & & \\
\hline MBA & $1(1)$ & & & \\
\hline MSc & $24(32)$ & & & \\
\hline $\mathrm{PhD}$ & $19(25)$ & & & \\
\hline Other & $2(3)$ & & & \\
\hline Would you like to complete a fellowship? (\%) & & $65(86)$ & $10(13)$ & $1(1)$ \\
\hline \multicolumn{5}{|l|}{ Where would-you like to complete your fellowship? (\%) } \\
\hline Canada & $12(16)$ & & & \\
\hline United States & $52(69)$ & & & \\
\hline Europe & $3(4)$ & & & \\
\hline Other & $1(1)$ & & & \\
\hline Unsure & $8(10)$ & & & \\
\hline Would you like to incorporate research as part of your practice? (\%) & & $56(75)$ & $13(17)$ & $6(8)$ \\
\hline Would you like to work in an academic institution? (\%) & & $60(80)$ & $12(16)$ & $3(4)$ \\
\hline Would you like to work in a community hospital? (\%) & & $8(11)$ & $36(49)$ & $30(40)$ \\
\hline \multicolumn{5}{|l|}{ Where would-you like to practice? (\%) } \\
\hline Canada & $45(59)$ & & & \\
\hline United States & $6(8)$ & & & \\
\hline Europe & $0(0)$ & & & \\
\hline Other & $6(8)$ & & & \\
\hline Unsure & $19(25)$ & & & \\
\hline Are you confident in finding a job? (\%) & & $28(37)$ & $23(31)$ & $24(32)$ \\
\hline
\end{tabular}

male (75\% of Canadians vs $79 \%$ of Americans vs $76 \%$ or Europeans), married (38\% of Canadians vs $51 \%$ of Americans), and without children (71\% of Canadians vs $68 \%$ of Americans). The interest in subspecialty training was significant and appears grossly proportional to the current Canadian staff positions, with spine, oncology, and vascular being the most represented. This contrasts with a survey conducted in 1996 in which the majority of practicing neurosurgeon worked as general neurosurgeons in academic centers ${ }^{5}$ and further confirms the trend toward a subspecialization within the field. ${ }^{6}$

\section{Workload}

With regard to work hours, $69 \%$ of Canadian residents reported working more than 80 hours/week, compared with $6 \%$ of Europeans, ${ }^{19}$ in whom the European Working Time Directive 2003/88/EC theoretically limits work hours to 48 per week.
Recent data were not available for the American programs, although a survey performed 1 year after the 2011 introduction of American work hour restrictions reported that $36 \%$ of neurosurgery residents violated the 80-hour regulation on an occasional or regular basis. ${ }^{17}$

The issue of work hour regulation is controversial. Proponents argue that an excessive workload negatively affects residents' physical and mental health and are associated with increased complications and unfavorable patient outcomes. ${ }^{20-22}$ Opponents stress that imposing work hour restrictions impedes continuity of care by increasing the number of caregivers, limits surgical exposure, and decreases resident performance with a detrimental effect on patient safety and resident employability. ${ }^{23,24}$

In our survey, although the majority of respondents felt that their workload was reasonable, a significant proportion of respondents $(42.5 \%)$ disagreed. Work-life balance was the only consistent source of dissatisfaction (17\% of respondents) among our cohort, 
Table 4: Wellbeing, quality of life, and satisfaction with residency

\begin{tabular}{|c|c|c|c|c|}
\hline & n $(\%)$ & High & Average & Low \\
\hline \multicolumn{5}{|l|}{ How would you rate your level of... } \\
\hline Happiness & & $45(59)$ & $28(37)$ & $3(4)$ \\
\hline Stress & & $40(53)$ & $30(39)$ & $6(8)$ \\
\hline Sense of accomplishment & & $37(49)$ & $33(43)$ & $6(8)$ \\
\hline Anxiety & & $22(29)$ & $32(43)$ & $21(28)$ \\
\hline Fatigue & & $37(50)$ & $31(41)$ & 7 (9) \\
\hline Workload & & $50(66)$ & $24(31)$ & $2(3)$ \\
\hline Quality of life & & $25(33)$ & $37(49)$ & $14(18)$ \\
\hline \multicolumn{5}{|l|}{ How would you rate your satisfaction with... } \\
\hline Choice of specialty & & $70(92)$ & $5(7)$ & $1(1)$ \\
\hline Choice of program & & $67(88)$ & $8(11)$ & $1(1)$ \\
\hline Surgical exposure & & $67(88)$ & $8(11)$ & $1(1)$ \\
\hline Work ambiance & & $52(68)$ & $18(24)$ & $6(8)$ \\
\hline Work-life balance & & $28(37)$ & $35(46)$ & $13(17)$ \\
\hline \multicolumn{5}{|l|}{ What is your level of confidence in... } \\
\hline Successfully completing residency & & $70(92)$ & $6(8)$ & $0(0)$ \\
\hline Becoming a competent neurosurgeon & & $70(92)$ & $6(8)$ & $0(0)$ \\
\hline \multicolumn{5}{|c|}{ Have you been victim of intimidation during residency? } \\
\hline Yes & $27(35)$ & & & \\
\hline No & $44(58)$ & & & \\
\hline Decline to answer & $5(7)$ & & & \\
\hline \multicolumn{5}{|c|}{ Have you suffered depression during residency? } \\
\hline Yes & $13(17)$ & & & \\
\hline No & $57(75)$ & & & \\
\hline Decline to answer & $6(8)$ & & & \\
\hline \multicolumn{5}{|c|}{ Have you considered suicide during residency? } \\
\hline Yes & $3(4)$ & & & \\
\hline No & $72(93)$ & & & \\
\hline Decline to answer & $2(3)$ & & & \\
\hline
\end{tabular}

with a rate comparable to that reported for practicing US neurosurgeons (14\%). ${ }^{25}$ Although less dramatic than the $32 \%$ and $38.9 \%$ reported for American and Canadian general surgery residents, respectively, ${ }^{26,27}$ dissatisfaction with work-life balance was higher than the $8.8 \%$ national average for residents across specialties. ${ }^{28}$ This phenomenon is not new. Indeed, an analysis of attrition in Canadian neurosurgery residency programs revealed a total attrition rate of $42.6 \%$ in the years 1980 through 1992 , with $65 \%$ of the affected residents voluntarily withdrawing from training mostly for lifestyle reasons. ${ }^{2}$ Moreover, a 2015 survey reported a $56 \%$ rate of burnout among American practicing neurosurgeons. ${ }^{29}$ Although data for neurosurgery residents are not available, a rate of $51.5 \%$ was reported for American internal medicine residents in $2011^{14}$ and $58 \%$ for general surgery residents in $2004 .^{30}$ Burnout was not directly assessed in our survey, although no respondent reported extending his or her residency for health reasons. It would be surprising, however, that burnout was nonexistent in neurosurgery, and this may reflect a response bias to the survey. We did, however, collect anecdotal evidence that research rotations are sometimes used to give residents "a break" from the workload of on-service rotations. Strategically placed research could perhaps represent a coping mechanism in the face of a demanding residency while also fulfilling academic objectives.

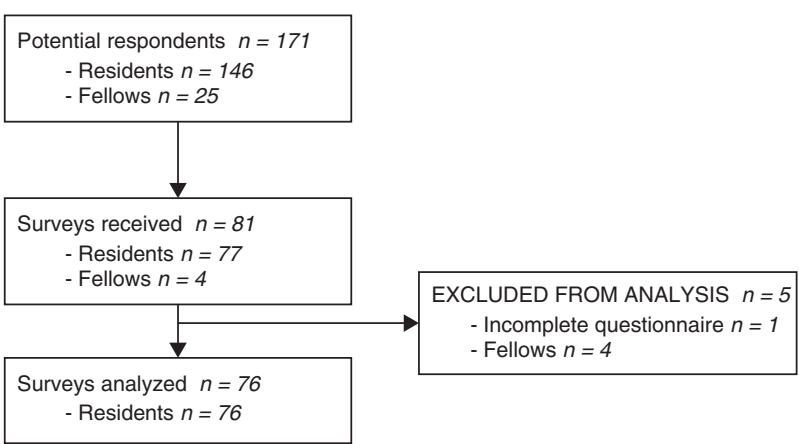

Figure 1: Flow diagram of survey respondents. 


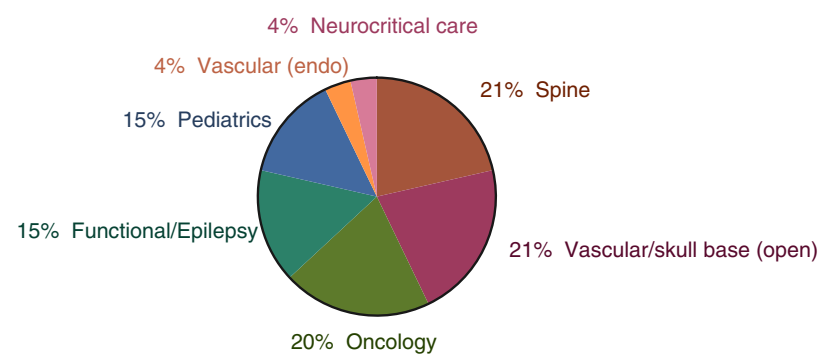

Figure 2: First choice of fellowship.

\section{Satisfaction and Quality of Life}

Respondent's satisfaction with their program (88\%) was higher than the 2013 national Canadian average across specialties $(62 \%) .{ }^{28}$ Neurosurgery residents' satisfaction in their choice of specialty $(92 \%)$ was comparable to rates reported for practicing American neurosurgeons $(95 \%)^{25}$ and substantially higher than orthopedic residents (69\%) and most surveys of attending surgeons from other surgical specialties including ear, nose, throat (ENT) (74\%); obstetrics and gynecology (76\%-89\%); plastics (67\%-80\%); and vascular (36\%). ${ }^{15}$ This might be related to a higher sense of accomplishment amongst neurosurgery residents. Indeed, only $8 \%$ of our respondents reported having a low sense of accomplishment relative to $13 \%$ to $40 \%$ of obstetrics and gynecology residents and $21 \%$ to $55 \%$ of ENT residents. ${ }^{15}$

Quality of life was reported as low by $18 \%$ of respondents. This was similar to general surgery residents' $18 \%{ }^{26}$ and ENT surgeons' $20.9 \%^{31}$ and higher than internal medicine residents' $14.5 \%{ }^{14}$ Yet, only $4 \%$ of respondents reported being unhappy. This discrepancy between quality of life and happiness might seem contradictory. We believe it reflects the temporary nature of residency in which quality of life is sacrificed until training is complete, competency is demonstrated, and a job is found. This overarching goal likely sustains happiness despite challenging circumstances. $^{32}$

\section{Intimidation}

Intimidation is a longstanding problem in residency training and workplace environment in general. A recent literature review reported that $45 \%$ to $93 \%$ of residents experienced some form of inappropriate behavior during training ${ }^{33}$; "intimidation or bullying," when specifically named as such, was reported by $30.8 \%$ of

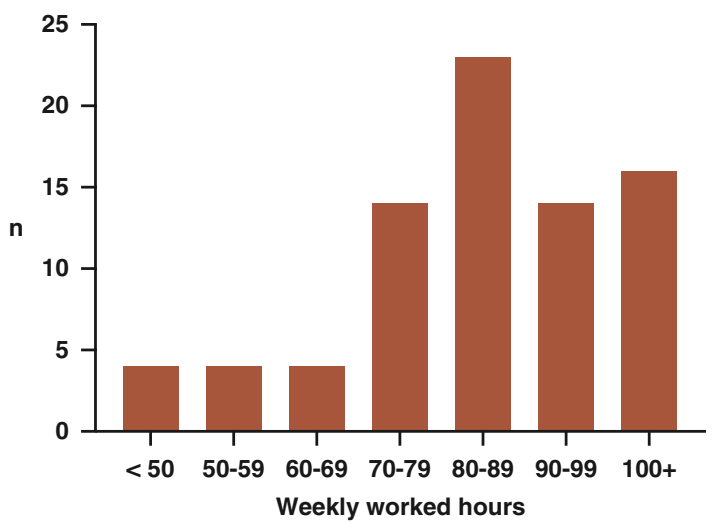

Figure 3: Self-reported worked hours in a typical week (including calls).
Canadian residents across specialties in $2013 .{ }^{28} \mathrm{~A}$ total of $44.7 \%$ of family medicine residents who graduated between 2001 and 2005 from two Canadian programs reported having experienced intimidation or harassment during residency training, ${ }^{34}$ and such behavior was reported by $16.7 \%$ of Canadian general surgery residents as a reason for considering leaving training. ${ }^{27}$ With a rate of $35 \%$ in our survey, neurosurgical programs are clearly affected by this problem as well. The well-known association between intimidation and depression is further confirmed by our data and highlights the importance of proactively fighting this problem.

\section{Limitations}

With a $52 \%$ response rate, our survey captured a sizeable sample of Canadian neurosurgery residents, and respondents were evenly distributed throughout training levels and provinces.

As an e-mail survey, our results do remain vulnerable to voluntary response bias. If, for example, residents with more time and energy proved more susceptible to answer, results could be skewed toward optimism. Concerns regarding respondents' anonymity could have further exacerbated this phenomenon because residents may have feared identification in small training programs with only one resident per year. Although participants were assured that only anonymous, aggregated data would be published, personal questions such as satisfaction with the program, intimidation, depression, and suicide could have acted as deterrents. On the other hand, the opposite could also be true and dissatisfaction might have motivated some residents to complete the survey.

\section{ConClusions}

The average, prototypical neurosurgery resident is a 29 -year-old single male with an interest in research. He works 80 to 89 hours per week with 7 nights on call per month, which he finds reasonable. Although he reports having a high level of stress and fatigue because of the high workload, he is generally happy and feels rewarded for his work. He is highly satisfied with his choice of specialty and considers a fellowship in spine, oncology, or open vascular surgery. He remains uncertain about his future employability.

\section{ACKNOWLEDGMENTS}

This study was made possible by the joint efforts of the Canadian Neurosurgery Research Collaborative (CNRC) steering committee members.

\section{Disclosures}

All authors declare having no conflict of interest.

\section{Statement of Authorship}

All authors contributed to the study design and implementation. CI-M collected the results, performed the statistical analysis, and drafted the manuscript. All authors critically revised the manuscript and approved the final version.

\section{SUPPLEMENTARY MATERIAL}

To view the supplementary material for this article, please visit https://doi.org/10.1017/cjn.2017.263. 


\section{REFERENCES}

1. Lubelski D, Healy AT, Friedman A, Ferraris D, Benzel EC, Schlenk R. Correlation of personality assessments with standard selection criteria for neurosurgical residency applicants. J Neurosurg. 2016;125:1-9.

2. Cusimano MD, Yonke AM, Tucker WS. An analysis of attrition from Canadian neurosurgery residency programs. Acad Med. 1999;74: 925-931.

3. Nadeem M, Effendi MS, Hammad Ather M. Attrition in surgical residency programmes: causes and effects. Arab J Urol. 2014;12: 25-29.

4. Lynch G, Nieto K, Puthenveettil S, et al. Attrition rates in neurosurgery residency: analysis of 1361 consecutive residents matched from 1990 to 1999. J Neurosurg. 2015;122:240-9.

5. Hugenholtz H. Neurosurgery workforce in Canada, 1996 to 2011. Canadian Neurosurgical Society. CMAJ. 1996;155:39-48.

6. Toyota BD. The impact of subspecialization on postgraduate medical education in neurosurgery. Surg Neurol. 2005;64:383-91.

7. Haji FA, Steven DA. Readiness for practice: a survey of neurosurgery graduates and program directors. Can J Neurol Sci. 2014;41:721-8.

8. Kondro W. New neurosurgeons left jobless: where's the plan? CMAJ. 2004;170:1377-8.

9. Woodrow SI, O'Kelly C, Hamstra SJ, Wallace MC. Unemployment in an underserviced specialty? The need for co-ordinated workforce planning in Canadian neurosurgery. Can J Neurol Sci. 2006;33:170-4

10. Dakson A, Tso MK, Ahmed SU, et al. Launch of the Canadian Neurosurgery Research Collaborative. Can J Neurol Sci. 2017;44: 204-206.

11. Linn LS, Yager J, Cope D, Leake B. Health status, job satisfaction, job stress, and life satisfaction among academic and clinical faculty. JAMA. 1985;254:2775-82.

12. Keeton K, Fenner DE, Johnson TRB, Hayward RA. Predictors of physician career satisfaction, work-life balance, and burnout. Obstet Gynecol. 2007;109:949-55.

13. West CP, Tan AD, Habermann TM, Sloan JA, Shanafelt TD. Association of resident fatigue and distress with perceived medical errors. JAMA. 2009;302:1294-300.

14. West CP, Shanafelt TD, Kolars JC. Quality of life, burnout, educational debt, and medical knowledge among internal medicine residents. JAMA. 2011;306:952-60.

15. Pulcrano M, Evans SRT, Sosin M. Quality of life and burnout rates across surgical specialties: a systematic review. JAMA Surg. 2016;151:970-8.

16. The American Association for Public Opinion Research. Standard Definitions: Final Dispositions of Case Codes and Outcome Rates for Surveys. 8th ed. AAPOR; 2015. Available at: http://www. aapor.org/Standards-Ethics/Standard-Definitions-(1).aspx.

17. Fargen KM, Dow J, Tomei KL, Friedman WA. Follow-up on a national survey: American neurosurgery resident opinions on the 2011 accreditation council for graduate medical educationimplemented duty hours. World Neurosurg. 2014;81:15-21.
18. Stienen MN, Netuka D, Demetriades AK, et al. Neurosurgical resident education in Europe-results of a multinational survey. Acta Neurochir. 2016;158:3-15.

19. Stienen MN, Netuka D, Demetriades AK, et al. Working time of neurosurgical residents in Europe-results of a multinational survey. Acta Neurochir. 2016;158:17-25.

20. Landrigan CP, Rothschild JM, Cronin JW, et al. Effect of reducing interns' work hours on serious medical errors in intensive care units. N Engl J Med. 2004;351:1838-48.

21. Samkoff JS, Jacques CH. A review of studies concerning effects of sleep deprivation and fatigue on residents' performance. Acad Med. 1991;66:687-93.

22. Weinger MB, Ancoli-Israel S. Sleep deprivation and clinical performance. JAMA. 2002;287:955-7.

23. Schaller K. Neurosurgical training under European law. Acta Neurochir. 2013;155:547-.

24. Stienen MN, Netuka D, Demetriades AK, et al. Working time of neurosurgical residents in Europe-results of a multinational survey. Acta Neurochir. 2016;158:17-25.

25. Klimo P, DeCuypere M, Ragel BT, McCartney S, Couldwell WT, Boop FA. Career satisfaction and burnout among U.S. neurosurgeons: a feasibility and pilot study. World Neurosurg. 2013;80: e59-68.

26. Antiel RM, Reed DA, Van Arendonk KJ, et al. Effects of duty hour restrictions on core competencies, education, quality of life, and burnout among general surgery interns. JAMA Surg. 2013;148: 448-455.

27. Ginther DN, Dattani S, Miller S, Hayes P. Thoughts of quitting general surgery residency: factors in Canada. J Surg Educ. 2016;73:513-7.

28. Canadian Association of Internes and Residents. 2013 national resident survey. Ottawa: Canadian Association of Internes and Residents; 2013. Available at: http://residentdoctors.ca/publications/ national-resident-survey/nrs-2013/.

29. McAbee JH, Ragel BT, McCartney S, et al. Factors associated with career satisfaction and burnout among US neurosurgeons: results of a nationwide survey. J Neurosurg. 2015;123:161-73.

30. Ishak WW, Lederer S, Mandili C, et al. Burnout during residency training: a literature review. J Grad Med Educ. 2009;1:236-42.

31. Balch CM, Shanafelt TD, Sloan JA, Satele DV, Freischlag JA. Distress and career satisfaction among 14 surgical specialties, comparing academic and private practice settings. Ann Surg. 2011;254:558-68.

32. Davenport DL, Henderson WG, Hogan S, Mentzer RM, Zwischenberger JB, Participants in the Working Conditions of Surgery Residents and Quality of Care Study. Surgery resident working conditions and job satisfaction. Surgery. 2008;144:332-5.

33. Karim S, Duchcherer M. Intimidation and harassment in residency: a review of the literature and results of the 2012 Canadian Association of Interns and Residents National Survey. Can Med Educ J. 2014;5:e50-7.

34. Crutcher RA, Szafran O, Woloschuk W, Chatur F, Hansen C. Family medicine graduates' perceptions of intimidation, harassment, and discrimination during residency training. BMC Med Educ. 2011;11:88. 